\title{
Pituitary responsiveness to LH-RH and TRH and the effects of progesterone or progesterone and oestradiol treatment in anoestrous sheep
}

\author{
P. J. Wright $\dagger$, G. Jenkin $\ddagger$, R. B. Heap and D. E. Walters* \\ A.R.C. Institute of Animal Physiology, Babraham, Cambridge CB2 4AT, and \\ *A.R.C. Statistics Group, Department of Applied Biology, University of Cambridge, \\ Pembroke Street, Cambridge, U.K.
}

\begin{abstract}
Summary. Pituitary responsiveness to $200 \mu \mathrm{g}$ synthetic $\mathrm{LH}-\mathrm{RH}$ and to $10 \mu \mathrm{g}$ TRH was determined in anoestrous sheep before and after treatment for 3 weeks with progesterone $(100 \mathrm{mg} /$ day $)$, or oestradiol $(250 \mu \mathrm{g} /$ day $)$ plus progesterone $(100 \mathrm{mg} /$ day $)$. There was a marked decrease in pituitary responsiveness to LH-RH after progesterone $(P<$ $0.01)$, or oestradiol + progesterone $(P<0.01)$ treatments, and an increase in response to TRH after oestradiol + progesterone $(P<0.01)$ treatment. The results demonstrate selective and simultaneous feedback effects of oestradiol and progesterone on pituitary responsiveness to two hypothalamic releasing hormones.
\end{abstract}

\section{Introduction}

Pituitary responsiveness to LH-RH declines progressively with advancing pregnancy in sheep. By 6-9 weeks after mating the amount of $\mathrm{LH}$ released in response to a standard injection of LH-RH decreases to $35 \%$, and by parturition to $14 \%$, of the value in anoestrous sheep (Jenkin \& Heap, 1974; Chamley, Findlay, Cumming, Buckmaster \& Goding, 1974a; Jenkin, Heap \& Symons, 1977). This decreased responsiveness is associated with a parallel fall in pituitary LH content (Chamley, Jonas \& Parr, 1976; Jenkin et al., 1977). A similar reduction in the release of FSH has been reported (Chamley, Findlay, Jonas, Cumming \& Goding, 1974b), but it was unaccompanied by a concomitant reduction in pituitary FSH content (Chamley et al., 1976).

Changes in pituitary responsiveness to LH-RH have been reported in women. Pituitary responsiveness is much reduced in pregnancy (Nakano et al., 1974; Jeppsson \& Rannevik, 1976; Jeppsson, Rannevik, Liedhoim \& Thorell, 1977), but recovers during the first few weeks after parturition (Jeppsson et al., 1977) or after therapeutic abortion in the second trimester (Jeppsson \& Rannevik, 1976). A similar recovery has been noted in sheep post partum (Jenkin et al., 1977).

The present study was designed to elucidate further the causes of these changes in pituitary responsiveness. Preliminary studies in intact sheep showed that the pituitary response to LH-RH is reduced by progesterone (Jenkin \& Heap, 1974; Jenkin, 1975). Pant \& Ward (1973) reported that daily injections of progesterone ( $20 \mathrm{mg}$ for 14 days) caused a decrease in pituitary responsiveness to injections of 2.5 and $5.0 \mathrm{ng} \mathrm{LH}-\mathrm{RH}$ in sheep during anoestrus, and this finding was confirmed in cyclic animals infused with progesterone $(500 \mu \mathrm{g} / \mathrm{h}$ for $76 \mathrm{~h}$ : Hooley et al., 1974). We have now examined the chronic effect of treatment with progesterone and oestrogen on pituitary responsiveness to determine whether the effect resembles that observed in pregnancy. The study has also been concerned with whether the change in pituitary responsiveness is confined to LH-RH or whether there are simultaneous alterations in pituitary responsiveness to other releasing hormones (e.g. TRH).

$\dagger$ Present address: School of Veterinary Science, University of Melbourne, Veterinary Clinical Centre, Princes Highway, Werribee, Victoria 3030, Australia.

¥ Present address: Nuffield Department of Obstetrics \& Gynaecology, John Radcliffe Hospital, Headington, Oxford OX3 9DU, U.K. 


\section{Materials and Methods}

Mature ewes predominantly of the Clun Forest breed were used during seasonal anoestrus (JuneAugust): all were non-pregnant and non-lactating and were kept in a paddock adjacent to the laboratory. Sheep were placed in individual pens at least $24 \mathrm{~h}$ before injection of releasing hormone and were allowed free access to food and water.

A polyvinyl catheter (Portex NT3, SH90; $1.4 \mathrm{~mm}$ i.d., $2.0 \mathrm{~mm}$ o.d.) was inserted $10 \mathrm{~cm}$ into a jugular vein on the day before releasing hormone was given. The basal concentration of LH and prolactin was measured in plasma from jugular venous blood samples taken over a 2 -h period before releasing hormones were injected.

\section{Hormone treatment}

$L H-R H$ and TRH. Sheep were given $200 \mu \mathrm{g}$ of the synthetic decapeptide, LH-RH, and $10 \mu \mathrm{g}$ of the synthetic tripeptide, TRH (Hoechst Pharmaceuticals), in $2 \mathrm{ml} 0.9 \%(\mathrm{w} / \mathrm{v}) \mathrm{NaCl}$ through the jugular catheter. In preliminary experiments these doses produced maximum plasma $\mathrm{LH}$ and prolactin release, and no interaction between the two releasing hormones was detected. Blood samples $(2.5 \mathrm{ml})$ were taken from the same catheter into heparinized syringes every $15 \mathrm{~min}$ for $2 \mathrm{~h}$ before and each $5 \mathrm{~min}$ for $0.5 \mathrm{~h}$ after injection, every $15 \mathrm{~min}$ for the next $1.5 \mathrm{~h}$, and then every $20-30 \mathrm{~min}$ for a further $4 \mathrm{~h}$.

Steroids. Progesterone and oestradiol-17ß (Sigma Chemical Co. Ltd) were prepared at appropriate concentrations in arachis oil and benzyl alcohol was added as preservative. At about 09:00 h each day for 3 weeks the sheep were given an intramuscular injection of $4 \mathrm{ml}$ arachis oil (Group 1), $100 \mathrm{mg}$ progesterone in $4 \mathrm{ml}$ arachis oil (Group 2), or $250 \mu \mathrm{g}$ oestradiol plus $100 \mathrm{mg}$ progesterone in $4 \mathrm{ml}$ arachis oil (Group 3).

\section{Pituitary responsiveness}

The responsiveness to LH-RH and TRH was determined on the day before treatment with steroids began and on the last day of treatment. Releasing hormones were injected at about 12:00 $\mathrm{h}$ and the response was measured in blood samples taken during the following $6 \mathrm{~h}$.

Plasma LH was measured by a solid-phase technique (Jenkin et al., 1977) and plasma prolactin by a double-antibody method based on a technique described by Hart (1972). All LH measurements were determined in one assay, and the intra-assay coefficient of variation for LH added to buffer was $11.7 \%$ $(7 \cdot 1 \mathrm{ng} \mathrm{NIH-LH}-\mathrm{S} 17 / \mathrm{ml} ; n=5)$. The lowest concentration of LH distinguishable from zero was $0.75 \pm 0.20$ (s.e.m.) $\mathrm{ng} / \mathrm{ml}$. In the prolactin assay the intra-assay coefficient of variation was $9 \cdot 9,11.5$ and $14.8 \%$ and the inter-assay coefficient of variation $14.4,15 \cdot 5$ and $20.3 \%$ for sheep plasma Pools 1 , 2 and $3(40 \cdot 7,60 \cdot 0$ and $221 \cdot 2$ ng of added NIH-prolactin-S1 $1 / \mathrm{ml} ; n=35)$. The blood for Pools 1,2 and 3 was taken from mature rams through an indwelling jugular catheter inserted on the previous day. The lowest concentration of prolactin distinguishable from zero was $5.0 \pm 2 \cdot 5$ (s.e.m.) $\mathrm{ng} / \mathrm{ml}$.

The basal values of $\mathrm{LH}$ and prolactin during a $2-\mathrm{h}$ period before treatment with LH-RH and TRH were integrated and transformed to natural logarithms. The responsiveness of the pituitary to LH-RH and TRH was assessed by measuring the total area under the curve of LH and prolactin release from 0 to $360 \mathrm{~min}$. The areas were calculated by the trapezoidal approximation (Abramowitz \& Stegun, 1968). Plasma LH and prolactin values returned to preinjection levels within $360 \mathrm{~min}$ after injection so that the area, expressed in $\mathrm{ng} / \mathrm{ml}$, was proportional to the total amount of hormone released. The time of injection was at $0 \mathrm{~min}$, and integrated values for the period of the experiment from -120 to 0 $\mathrm{min}$ are expressed as $(\mathrm{ng} / \mathrm{ml}) . \tau_{1}$, and from 0 to $+360 \mathrm{~min}$ as $(\mathrm{ng} / \mathrm{ml}), \tau_{2}$ (see Text-fig. 1 ).

Statistical analysis. Analysis of variance was carried out on the hormone concentration at each stage of the experiment, and to examine the pattern of change in pituitary responsiveness the appropriate functions of the concentrations for each sheep were analysed as advocated by Rowell \& Walters (1976). All analyses were carried out on logarithmically transformed variables. 


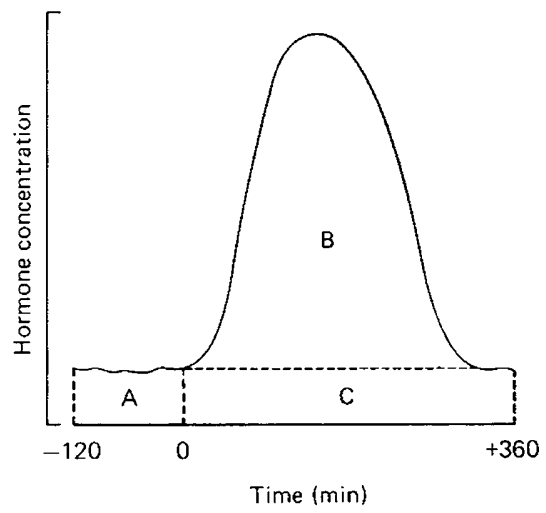

Text-fig. 1. Schematic diagram of LH or prolactin release measured in jugular vein plasma after an intravenous injection of LH-RH or TRH. Solid line is fitted to measured values of pituitary hormones. A refers to an integrated area $(\mathrm{ng} / \mathrm{ml}) . \tau_{1}$ which is proportional to the basal secretion of pituitary hormone. B refers to an integrated area $\left((\mathrm{ng} / \mathrm{ml}) . \tau_{1}\right)$ which is proportional to the increment of pituitary hormone secreted after an injection of releasing hormone. B plus $\mathrm{C}$, refers to an integrated area $\left((\mathrm{ng} / \mathrm{ml}) \cdot \tau_{2}\right)$ which is proportional to the total pituitary hormone secreted after the releasing hormone injection.

Table 1. Basal values of $\mathrm{LH}$ and prolactin, and integrated values of $\mathrm{LH}$ and prolactin release after the simultaneous intravenous injection of $200 \mu \mathrm{g} \mathrm{LH}-\mathrm{RH}$ and $10 \mu \mathrm{g}$ TRH in anoestrous sheep treated for 3 weeks with vehicle, progesterone or oestradiol + progesterone

\begin{tabular}{|c|c|c|c|}
\hline & \multicolumn{3}{|c|}{ Treatment } \\
\hline & $\begin{array}{l}\text { Vehicle only } \\
\text { (Group 1) }\end{array}$ & $\begin{array}{l}\text { Progesterone } \\
\text { (Group 2) }\end{array}$ & $\begin{array}{l}\text { Oestradiol + } \\
\text { progesterone } \\
\text { (Group 3) }\end{array}$ \\
\hline No. of animals & 4 & 5 & 5 \\
\hline \multicolumn{4}{|l|}{ LH } \\
\hline \multicolumn{4}{|c|}{ Basal values $\left(\log _{\mathrm{e}} \mathrm{ng} / \mathrm{ml}\right)$} \\
\hline Before treatment & $1.34 \pm 0.23(3.8)$ & $1 \cdot 14 \pm 0.20(3 \cdot 1)$ & $1.28 \pm 0.20(3.6)$ \\
\hline After treatment & $1.70 \pm 0.36(5.4)$ & $0.77 \pm 0.32(2.1)$ & $0.50 \pm 0.32(1.6)$ \\
\hline \multicolumn{4}{|c|}{ Integrated basal values $\left(\log _{\mathrm{e}} \mathrm{ng} / \mathrm{ml} . \tau_{1}\right) \dagger$} \\
\hline Before treatment & $6.05 \pm 0.23(0.42)$ & $5.88 \pm 0.20(0.36)$ & $6.09 \pm 0.20(0.44)$ \\
\hline After treatment & $6.62 \pm 0.39(0.75)$ & $5.65 \pm 0.35(0.29)$ & $5.19 \pm 0.35(0.17)$ \\
\hline \multicolumn{4}{|c|}{ After LH-RH $\left(\log _{\mathrm{e}} \mathrm{ng} / \mathrm{ml} . \tau_{2}\right) \dagger \ddagger$} \\
\hline Before treatment & $10 \cdot 27 \pm 0.29(28.85)$ & $10.44 \pm 0.26(34 \cdot 20)$ & $10.25 \pm 0.26(28 \cdot 28)$ \\
\hline After treatment & $10.08 \pm 0.16(23.86)$ & $8.81 \pm 0.15(6.70)^{*}$ & $7.56 \pm 0.15(1.92)^{*}$ \\
\hline \multicolumn{4}{|l|}{ Prolactin } \\
\hline \multicolumn{4}{|c|}{ Basal values $\left(\log _{\mathrm{e}} \mathrm{ng} / \mathrm{ml}\right)$} \\
\hline Before treatment & $3.75 \pm 0.28(42 \cdot 4)$ & $3.52 \pm 0.24(33.9)$ & $3.59 \pm 0.25(36.2)$ \\
\hline After treatment & $4.27 \pm 0.33(71 \cdot 7)$ & $4.30 \pm 0.29(73.8)$ & $4.82 \pm 0.29(123.8)$ \\
\hline \multicolumn{4}{|c|}{ Integrated basal values $\left(\log _{\mathrm{e}} \mathrm{ng} / \mathrm{ml} . \tau_{1}\right) \dagger$} \\
\hline Before treatment & $8.48 \pm 0.28(4.81)$ & $8.25 \pm 0.25(3.81)$ & $8.33 \pm 0.25(4 \cdot 15)$ \\
\hline After treatment & $9.14 \pm 0.30(9.32)$ & $8.90 \pm 0.27(7.35)$ & $9.48 \pm 0.27(13.15)$ \\
\hline \multicolumn{4}{|c|}{ After TRH $\left(\log _{\mathrm{c}} \mathrm{ng} / \mathrm{ml} . \tau_{2}\right) \dagger \ddagger$} \\
\hline Before treatment & $10.58 \pm 0.23(39 \cdot 34)$ & $10 \cdot 26 \pm 0.20(28.57)$ & $10.19 \pm 0.20(26.64)$ \\
\hline After treatment & $10.75 \pm 0.23(46.63)$ & $10.77 \pm 0.20(47.57)$ & $12.02 \pm 0.20(166.04)^{*}$ \\
\hline
\end{tabular}

Results are given as $\log _{e}$ mean \pm s.e.m. with arithmetic mean values in parentheses.

* Value significantly different from that obtained before treatment, $P<0 \cdot 01$.

+ Arithmetic values $\times 10^{-3}$.

$\ddagger$ Integrated values. 


\section{Results}

The basal concentrations of $\mathrm{LH}$ and prolactin in plasma are given in Table 1 . The concentration of each hormone was similar in all three groups of animals before steroid hormone treatment. After 3 weeks of treatment, mean plasma LH concentrations appeared to decrease and mean plasma prolactin concentrations appeared to increase in the animals in Groups 2 and 3 but the changes were not statistically significant. There was no significant change in hormone concentrations in Group 1 animals treated with vehicle only.

The integrated basal values of plasma $\mathrm{LH}$ and prolactin estimated before injection of releasing hormones are given in Table 1. A gradation was again noted in the difference between the basal values before and after steroid hormone treatment: in Group 1 there was a relatively small change in both hormones, in Group 2 there was a decrease in $\mathrm{LH}$ values and a small increase in prolactin values, and in Group 3 there was an even greater reduction in $\mathrm{LH}$ values, but a two-fold increase in prolactin values. These observed differences associated with the effect of hormone treatment failed to reach statistical significance, perhaps because of the small number of animals in each group.

Pituitary responsiveness to LH-RH and TRH determined before and after steroid treatment is also shown in Table 1. In animals treated with progesterone (Group 2) there was a substantial decrease in the LH-RH-induced release of LH $(P<0.01)$, and a small increase in TRH-induced prolactin release. Treatment with oestradiol and progesterone (Group 3 ) produced an even more marked decrease in LH release $(P<0.01)$, and a significant increase in prolactin release $(P<0.01)$. There were no changes in the control animals.

Pituitary responsiveness to LH-RH and TRH was also evaluated by measuring the area under the curve of hormone release after subtracting the basal concentration in plasma. This calculation corrected for the change in basal concentration in plasma after steroid treatment. The results (not given) showed a very similar effect to that described above, with a reduction in pituitary responsiveness to LH-RH after progesterone $(P<0.01)$ or oestradiol + progesterone $(P<0.01)$ treatment, and an increase in response to TRH only after oestradiol + progesterone $(P<0.01)$ treatment.

\section{Discussion}

Progesterone and oestradiol treatment of anoestrous sheep resulted in marked changes in pituitary responsiveness to the two releasing hormones studied, LH-RH and TRH. When oestradiol and progesterone were administered together at a daily dose similar to the rate of production in late pregnancy (Bedford, Harrison \& Heap, 1972; Challis, Harrison \& Heap, 1973a), pituitary responsiveness to LH-RH was reduced to $8 \%$ of the value in control aminals. The magnitude of this decline was greater than that found in animals treated only with progesterone $(28 \%)$, and was similar to that observed late in normal pregnancy (Jenkin et al., 1977). Responsiveness to LH-RH decreases slowly, but progressively during gestation, whereas our present findings in anoestrous sheep show that the same effect can be produced experimentally with 3 weeks of steroid treatment. The findings confirm our earlier suggestion (Jenkin \& Heap, 1974) that progesterone has a major part in the reduction of pituitary responsiveness to $\mathrm{LH}-\mathrm{RH}$, but it is apparent that the effect may be even more pronounced with the simultaneous administration of oestrogen.

Whereas oestrogen + progesterone treatment had a negative feedback effect on pituitary responsiveness to $\mathrm{LH}-\mathrm{RH}$, a positive influence was noted with respect to TRH and there was a 4 -fold increase in prolactin release. In contrast, animals treated only with progesterone showed no change in the response to TRH. It should be noted, however, that although TRH is valuable for the study of pituitary regulation it is not yet known whether TRH has a physiological role in prolactin release in sheep, nor whether TRH secretion is affected during gestation.

The feedback effect of progesterone on LH release, and of oestrogen on prolactin release have been described in various species (see McCann, 1974; Brown-Grant, 1977). In the present experiments the effect of treatment with oestrogen alone was not studied as the primary intention was to identify causal factors involved in changes in pituitary responsiveness in gestation. In the last third of preg- 
nancy, oestrogen and progesterone production both increase (Févre, Piton \& Rombauts, 1965; Bedford et al., 1972), and during the last $48 \mathrm{~h}$ of gestation oestrogen production undergoes a further sharp increase (Challis et al., 1973a, b) as progesterone production declines. McNeilly (1971) noted that plasma prolactin concentrations in sheep increased for about 3 weeks from about Day 100 of gestation and then decreased. These changes were followed by a second peak at parturition and then a gradual decline over a 3-week period post partum. These findings may be related to a change in pituitary responsiveness associated with a positive feedback effect of oestrogen, although the transient fall in prolactin concentrations observed 2-3 weeks before parturition remains inexplicable.

In the light of our present findings in anoestrous sheep, the reduction previously reported in pituitary responsiveness to LH-RH in pregnancy may be accompanied by an increased responsiveness to TRH and this aspect requires further study. The findings support the idea (Chamley et al., 1976) that the chronic influence of steroid feedback on pituitary responsiveness to releasing hormones is selective. Thus, progesterone appears to reduce pituitary responsiveness to $\mathrm{LH}-\mathrm{RH}$, which is associated with a concomitant reduction of pituitary stores. The effect may be enhanced in late pregnancy by placental oestrogen secretion. The negative feedback effect of progesterone may also be responsible for the observed decline in LH-RH-induced FSH release that occurs during gestation (Chamley et al., 1974b). This decline, however, cannot be readily explained by a reduction in pituitary FSH content, which remains unchanged until just before parturition (Chamley et al., 1976). The latter finding suggests that modifications in pituitary responsiveness to LH-RH are not caused simply by a depletion of the gonadotroph population, but by an alteration of either the mechanism of release or synthesis of FSH and LH. Further evidence for the selective nature of this change in pituitary responsiveness was provided by Chamley et al. (1976) who showed that the pituitary content of growth hormone did not change with advancing pregnancy. Our findings in non-pregnant sheep treated with oestradiol and progesterone demonstrate, therefore, that alterations in pituitary responsiveness to LH-RH may be accompanied by changes in response to at least one other synthetic hypothalamic releasing hormone, and that these changes can occur simultaneously and in opposite directions.

We thank the Lalor Foundation for a Research Fellowship (G. J.); Mr J. M. J. Best, Hoechst Pharmaceuticals, Hounslow, Middlesex, for gifts of releasing hormones; Dr L. E. Reichert and the National Institutes of Health, Bethesda, Maryland, U.S.A., for pituitary hormones; and Dr J. R. McNeilly for a gift of prolactin antiserum.

\section{References}

Abramowitz, M. \& Stegun, I.A. (1968) Handbook of Mathematical Functions, p. 885. Dover Publications, Inc., New York.

Bedford, C.A., Harrison, F.A. \& Heap, R.B. (1972) The metabolic clearance rate and production rate of progesterone and the conversion of progesterone to $20 \alpha$-hydroxypregn-4-en-3-one in the sheep.J. Endocr. 55, 105-118.

Brown-Grant, K. (1977) Physiological aspects of the steroid hormone-gonadotropin interrelationship. Int. Rev. Physiol., Reproductive Physiology II, Vol. 13, pp. 57-83. Ed. R. O. Greep. University Park Press, Baltimore.

Challis, J.R.G., Harrison, F.A. \& Heap, R.B. (1973a) The kinetics of oestradiol-17 $\beta$ metabolism in the sheep. J. Endocr. 57, 97-110.

Challis, J.R.G., Harrison, F.A. \& Heap, R.B. (1973b) The metabolic clearance rate and conversion ratios of oestrone in the sheep. J. Endocr. 58, 435-446.

Chamley, W.A., Findlay, J.K., CUmming, I.A., BUCKMASTER, J.M. \& Goding, J.R. (1974a) Effect of pregnancy on the LH response to synthetic gonadotropin-releasing hormone in the ewe. Endocrinology 94, 291-293.
Chamley, W.A., Findlay, J.K., Jonas, H., Cumming, I.A. \& Goding, J.R. (1974b) Effect of pregnancy on the FSH response to synthetic gonadotrophin releasing hormone in ewes. J. Reprod. Fert. 37, 109112.

Chamley, W.A., Jonas, H.A. \& ParR, R.A. (1976) Content of LH, FSH and growth hormone in the pituitaries of pregnant and anestrous sheep. Endocrinology 98. $1535-1538$

Févre, J.C., Piton, C. \& Rombauts, P. (1965) Etude des oestrogènes urinaires chez la brebis gestante. C. $r$. hebd. Seanc. Acad. Sci., Paris 261, 2517-2520.

HART, I.C. (1972) A solid phase radioimmunoassay for ovine and caprine prolactin using Sepharose 6B: its application to the measurement of circulating levels of prolactin before and during parturition in the goat. J. Endocr. 55, 51-62.

Hooley, R.D., Baxter, R.W., Chamley, W.A., Cumming, I.A., Jonas, H.A. \& Findlay, J.K. (1974) FSH and LH response to gonadotropin-releasing hormone during the ovine estrous cycle and following progesterone administration. Endocrinology 95, 937942. 
Jenkin, G. (1975) Pituitary function in the sheep; factors affecting the synthesis and release of luteinizing hormone. Ph.D. thesis, University of Cambridge.

JENKIN, G. \& HEAP, R.B. (1974) The lack of response of the sheep pituitary to luteinizing releasing hormone stimulation in gestation and early lactation; the probable role of progesterone. J. Endocr. 61, xii-xiii.

Jenkin, G. Pituitary responsiveness to synthetic LH-RH and pituitary LH content at various reproductive stages in the sheep. J. Reprod. Fert. 49, 207-214.

JEPPSSON, S. \& RANNEviK, G. (1976) Studies on the gonadotropin response after administration of LH/FSH-releasing hormone (LRH) during pregnancy and after therapeutic abortion in the second trimester. Am. J. Obstet. Gynec. 125, 484-490.

JePPSSON, S., RANNEviK, G., Liedholm, P. \& ThORell, J.I. (1977) Basal and LRH-stimulated secretion of FSH during early pregnancy. Am. J. Obstet. Gynec. $127,32-36$.
McCanN, S.M. (1974) Regulation of secretion of folliclestimulating hormone and luteinizing hormone. In Handbook of Physiology, Section 7: Endocrinology, Vol. 4, part 2, pp. 489-518. Eds R. O. Greep \& E. B. Astwood, American Physiological Society, Washington D.C.

MCNeILlY, J.R. (1971) A solid phase radioimmunoassay for ovine prolactin. J. Endocr. 49, 141-149.

Nakano, R., Kayashima, F., Katayama, K., Mizuno, T., WASHIO, M. \& Tojo, S. (1974) The radio-immunoassay of follicle-stimulating hormone ( $\mathrm{FSH}$ ) during human pregnancy: serum concentration and response to luteinizing hormone releasing factor. Acta obstet. gynec. scand. 53, 259-262.

PANT, H.C. \& WARD, W.R. (1973) Effect of progesterone on the pituitary responsiveness to luteinizing hormone releasing hormone ( $\mathrm{LH}-\mathrm{RH}$ ) in intact anoestrous ewes. J. Physiol., Lond. 232, 45P-48P.

RowelL, J.G. \& WALTERS, D.E. (1976) Analysing data with repeated observations on each experimental unit. J. agric. Sci., Camb. 87, 423-432.

Received 12 August 1977 